DOI 10.37882/2223-2982.2021.08.41

\title{
ИССЛЕДОВАНИЕ МОДЕЛИ ПОДГОТОВКИ ЮРИДИЧЕСКИХ СПЕЦИАЛИСТОВ, СВЯЗАННЫХ С ИНОСТРАННЫМИ ДЕЛАМИ В КИТАЕ
}

\section{RESEARCH OF THE MODEL OF TRAINING OF LEGAL SPECIALISTS RELATED TO FOREIGN AFFAIRS IN CHINA}

Yue Qiang

Summary: In February 2021, the Ministry of Education and the Ministry of Justice jointly identified 15 universities as universities for training Masters of Law (lawyers related to foreign affairs). This article analyzes the legal and political foundations for the implementation of this project, examines the model of training project specialists and suggests ways and methods of promoting and improving the project.

Keywords: preparation of masters of law, project of the CPC Central Committee, access to the global level.

\section{Значимость осушествления проекта}

C егодняшний мир переживает беспрецедентные за столетие изменения, структура глобального управления претерпевает глубокую корректировку, международная обстановка становится все более и более сложной, значительно возросли нестабильность и неопределенность[1]. По мере того как Китай приближается к центру мировой сцены и все глубже вовлекается в глобальное управление, а также по мере того, как китайские предприятия и граждане продолжают ускорять темпы выхода на глобальный уровень, Китаю срочно необходимо ускорить стратегическое планирование юридической работы, связанной с иностранными государствами, содействовать развитию юридических услуг, связанных с иностранными государствами, и обучать большое количество юристов, связанных с иностранными государствами, которые знакомы с международными правовыми нормами и хорошо разбираются в правовых вопросах, связанных с иностранными государствами. Для лучшей защиты интересов национального суверенитета, безопасности и развития, защиты законных прав и интересов отечественных предприятий и граждан за рубежом, а также обеспечения и сохранения высокого уровня открытости внешнему миру, Китай осуществил проект по подготовке юристов, имеющих отношение к
Юэ Цян

К.гум.н., старший преподаватель, Шанхайский политикоюридический университет; пост-доктор, Восточнокитайский политико-юридический университет; Замначальника, Центр исследований при Комиссии по юридическим услугам для ШОС (Китай) yueqiang850510@sina.com

Аннотация: В феврале 2021 года Министерство образования и Министерство юстиции совместно определили 15 университетов в качестве вузов для подготовки магистров права (юристов, имеющих отношение к иностранным делам). В этой статье анализируются правовые и политические основы реализации данного проекта, рассматривается модель обучения специалистов проекта, и предлагаются пути и методы продвижения и совершенствования проекта.

Ключевые слова: подготовка магистров права, проект ЦК КПК, выход на глобальный уровень.

иностранным делам [2].

\section{Правовая и политическая основа}

Впервые в решении ЦК КПК по ряду важных вопросов, касающихся всеобъемлющего правового управления в стране, которое было рассмотрено и принято на четвертом Пленарном заседании 18-го созыва ЦК КПК, прямо предложено в форме партийных документов развитие юридической работы, связанной с иностранными государствами.[3]

25 февраля 2019 года на втором пленарном заседании Центрального комитета по общему верховенству закона Генеральный секретарь Си Цзиньпин указал, что необходимо ускорить создание правовой системы, применимой за пределами юрисдикции национальных законов Китая, и ускорить создание правовой системы, применимой за пределами юрисдикции национальных законов Китая. Необходимо усилить подготовку юридических специалистов, связанных с иностранными делами, активно развивать юридические услуги, связанные с иностранными, укреплять чувство соответствия предприятий для обслуживания открытости внешнему миру. [4] 
В феврале 2021 года Министерство образования и Министерство юстиции совместно назначили 15 университетов в качестве вузов по подготовке магистров права (юристов, связанных с иностранными государствами) в целях дальнейшей реализации духа важных указаний Генерального секретаря Си Цзиньпина о развитии подготовки специалистов, связанных с иностранными государствами. 15 университетов расположены в 7 городах по всей стране, в частности, в Пекине 5 (Пекинский университет, Университет Цинхуа, Китайский народный университет, Китайский университет политических наук и права, Университет международного бизнеса и экономики), в Шанхае 3 (Университет Фудань, Восточно-Китайский политико-юридический университет, Шанхайский политико-юридический университет), в Ухане 2 (Уханьский университет, Чжуннаньский университет экономики и права), в Чунцине 1 (Юго-Западный политико-юридический университет), в Гуанчжоу 2 (Университет Сунь Ятсена, Гуандунский университет иностранных языков), в Чанчуне 1 (Цзилиньский университет), в Сиане 1 (Северо-Западный политико-юридический университет). Планируется, что эти вузы впервые примут в программу около 500 студентов в 2021 году.

\section{Модель обучения спешиалистов}

Генеральный секретарь Си Цзиньпин сделал важное заявление о том, как подготовить юридических специалистов в новую эпоху, указав, что необходимо разрушить институциональные барьеры между университетами и обществом, внедрить высококачественные практические учебные ресурсы с кафедр практической работы в вузы, укрепить сотрудничество между вузами и их предприятиями, местными органами власти и академиями и в полной мере использовать активную роль правительств, судов, прокуратур, юридических фирм и предприятий в подготовке юридических специалистов. Товарищи, занимающиеся юридическим образованием и юридической исследовательской работой, и товарищи по отделу практической работы по вопросам верховенства закона должны общаться друг с другом, учиться у сильных сторон друг друга и лучше сочетать юридическую теорию и судебную практику. [5] Отделы практической работы направляют специалистов с более высоким теоретическим уровнем для преподавания в вузах, должны участвовать в разработке программ подготовки специалистов, в разработке системы учебных программ, учебных материалов, профессиональном обучении, привнести в учебную программу новейший опыт и яркие примеры практики построения социалистической страны в условиях верховенства закона.[6]

В целом, основная часть организации и реализации проекта «Магистр права» (юрист, связанный с иностранными делами) включает в себя пять аспектов: компе- тентные департаменты отрасли, компетентные департаменты образования, организации профессионального образования, подразделения по реализации проектов и совместные учебные подразделения. Среди них Департамент управления образованием и высшим образованием Министерства образования и Бюро по работе с юристами Министерства юстиции являются ведущими подразделениями в организации реализации проекта, первое-это подразделение по подготовке специалистов, то есть административный отдел юридического факультета, который занимается реализацией проекта; второе - отраслевой департамент в области спроса на специалисты. Являясь авторитетным компетентным подразделением юридической профессии, участие Бюро юристов в обучении специалистов подчеркивает внимание, уделяемое компетентными подразделениями отрасли подготовке специалистов, тесной интеграции подготовки юридических специалистов и юридической профессии, и обеспечивает гарантию того, что в полной мере будет играть роль отделов юридической практики и выделения высококачественных ресурсов отделов практики. Реформа системы набора и подготовки сотрудников политической и правовой полиции, осуществленная в Китае десять лет назад, «План двойной тысячи» для взаимного набора между университетами и отделами юридической практики, реализованный в 2013 году, и план обучения и подготовки выдающихся юридических (правоохранительных) специалистов - всё это способы, с помощью которых компетентные департаменты образования и компетентные департаменты отрасли совместно содействуют подготовке специалистов. В этот раз Министерства юстиции и образования совместно руководили организацией и осуществлением проекта, тоже следуя этой рабочей модели.

В соответствии с положениями руководящей учебной программы высшие учебные заведения, в соответствии со своими профессиональными условиями, особенностями и географическими преимуществами, устанавливают междисциплинарные модели обучения, такие как право и иностранные языки, политология и прикладная экономика, а также разрабатывают и внедряют дифференцированную и характерную модель обучения «право + иностранные языки+N», где «N» включает специальности в других смежных дисциплинах, помимо права, особенно в области международной политики и международных отношений, национальных или региональных, международных организаций, финансов, прикладной статистики, бухгалтерского учета, налогообложения, международного бизнеса, страхования, оценки активов, аудита и т.д. Это означает, что подразделение по реализации проекта может осуществлять межвузовское, межрегиональное сотрудничество и учебную работу с другими соответствующими колледжами на территории кампуса или за его пределами. 


\section{Пути и способы продвижения проекта подготовки}

\section{(1) Продвижение инновационного режима обучения с помошью коншепции совместного обучения}

Вузы могут использовать образовательные ресурсы, как на территории кампуса, так и за его пределами, ориентироваться на национальные стратегические потребности, инвестировать свои собственные преимущества и возможности в области ресурсов, повышать профессиональные способности студентов за счет совместного использования ресурсов, взаимного сотрудничества и координации, а также создавать долгосрочный механизм для многопредметного совместного обучения. Особое внимание следует уделять сотрудничеству между дисциплинами, с правоохранительными органами и с международным сотрудничеством.

\section{(2) Создание оптимизированной системы учебных} программ, ориентированных на иностранные и практические потребности

Во-первых, интенсивное обучение иностранного права, что является не только профессиональными знаниями, которыми должна обладать юридическая работа, связанная с иностранцами, но и основными условиями предоставления юридических услуг для будущего «выхода на глобальный уровень».

Во-вторых, для стран-членов ШОС в обучении международного права, международного частного права и международного экономического права могут применять русско-англо-китайское трехъязычное или русскоанглийское двуязычное преподавание, Поскольку иностранный юридический специалист, обслуживающий юридическую дипломатию в рамках ШОС, использует международные правила в основном на основе двуязычного выражения на русском и английском языках, по таким моделям обучения может улучшиться способность студентов в этом отношении.

(3) Ускорение разработки высококачественных

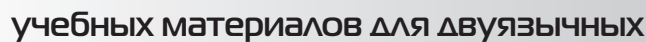
и иностранных $\Delta$ ел

Во-первых, сочетание интернационализации и локализации в режиме подготовки и содержании трехъязычных учебных материалов. Например, подготовка русско-англо-китайских трехъязычных учебных материалов подходит для использования русско-англо-китайского режима сравнения китайского и русско-английского языков с точки зрения языкового соответствия; добавление китайских элементов в содержание учебных материалов. В области китайского юридического образования сложилась традиция скромного обучения у других стран, которая глубоко повлияла на концепцию интер- национализации вузов, так что большинство университетов по-прежнему фокусируются на роли обучения и игнорируют роль участия.

Во-вторых, ускорение разработки учебных материалов для дел, связанных с иностранными странами. Еще одной особенностью учебной программы подготовки юридических специалистов, связанных с иностранными делами, является практический характер. Тематическое исследование является одной из основных форм, используемых в курсах юридической практики, связанных с иностранными.

\section{(4) Сотрудничество в совместном обучении и «стыковка» китайского и зарубежного юрихического образования}

Студенты из стран ШОС и китайские студенты могут обучаться одновременно через систему дистанционного онлайн-образования. Этот «зеленый канал обучения» также способствует интернационализации учебной среды и эффективному и экономичному использованию зарубежных ресурсов юридического образования.

\section{Зак^ючение}

Проект Магистра права (Юрист, связанный с иностранными делами) - это конкретная мера по реализации стратегического плана работы государства по обеспечению верховенства закона в иностранных делах. Это специальный проект Магистра юридического образования и новая попытка изучить и подготовить юридических специалистов, связанных с иностранными делами.

Благодаря реализации программы подготовки выпускников магистратуры по специальности юрист (юрист, связанный с иностранными делами) проект поддерживает соответствующие университеты и правоохранительные органы в активном изучении и внедрении инноваций в способ подготовки юридических специалистов высокого уровня, занимающихся вопросами, связанными с иностранными делами, совершенствовании системы подготовки юридических специалистов высокого уровня с китайской спецификой, играет ведущую роль в обучении группы юристов высокого уровня, отвечающих требованиям, прикладных и международных юридических специалистов с твердыми политическими позициями, отличным профессиональным качеством, междисциплинарными областями и хорошо решающих практические проблемы, а также закладывает основу для создания команды юристов, связанных с иностранными делами, с профессиональными юридическими навыками, международной перспективой, знакомством с международными правовыми нормами и хорошо разбирающихся в юридических вопросах, связанных с иностранными делами. 


\section{ЛИТЕРАТУРА}

1. Хуан Цзинь. «Совершенствование системы правовой дисциплины и инновация механизмов подготовки юридических специалистов, имеющихся отношение с иностранными делами» Времена демократии и верховенства закона 01.05.2020

2. Юань Динбо. «Министерство юстиции: добросовестно выполняет свои обязанности и стремится хорошо выполнять свою работу в сфере юридических услуг»"Юридический Ежедневник" 21.05. 2015.

3. People's Daily Overseas Network. «0бзор зарубежной сети: построение верховенства права, связанное с зарубежными странами, является важной коннотацией мысли Си Цзиньпина о верховенстве права»

4. Хуан Хуэйканг. «Координация усилий по содействию верховенству права в Китае и верховенству права во внешних делах» Народная сеть http://theory.people.com.cn/n1/2021/0127/c40531-32013474.html

5. Ху Мин. «Инновационная модель юридического образования, подготовка как нравственных, так и высококвалифицированных специалистов в области верховенства права» «Высшее образование в Китае» 2018(9)

6. «Создание прочной основы для юридического образования и создание прочной основы для людей» Гуанмин Ежедневник 12.11.2019 https://news.gmw.cn/2019-11/12/content_33311429.htm

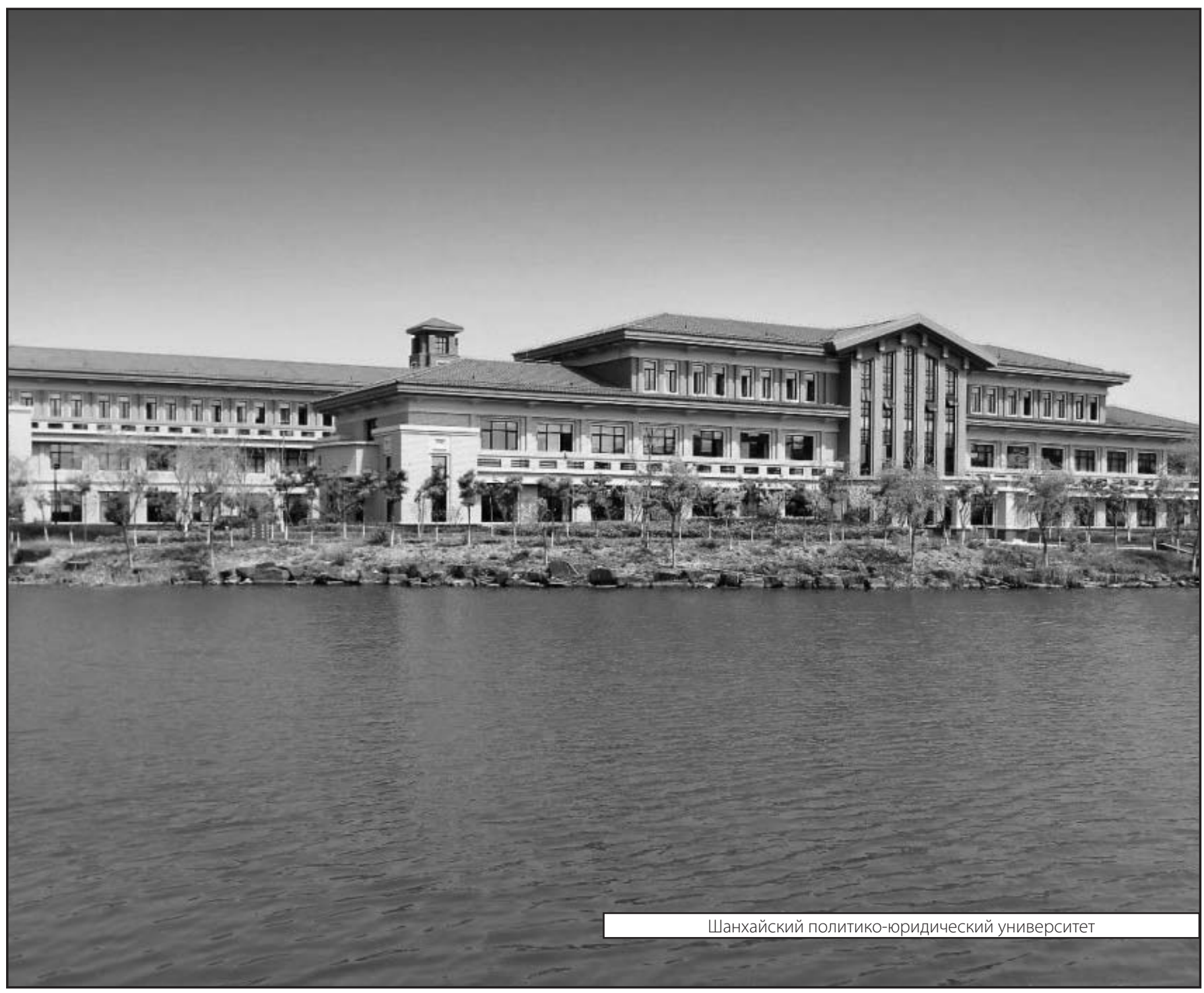

